\title{
Analysis of Receptive Vocabulary Development in Williams Syndrome
}

\author{
Esther Moraleda Sepúlveda, Patricia López \\ Universidad de Castilla-La Mancha, Talavera de la Reina, Spain \\ Email: esther.moraleda@uclm.es
}

How to cite this paper: Moraleda Sepúlveda, E., \& López, P. (2020). Analysis of Receptive Vocabulary Development in Williams Syndrome. Open Journal of Modern Linguistics, 10, 804-812.

https://doi.org/10.4236/ojml.2020.106050

Received: November 5, 2020

Accepted: November 30, 2020

Published: December 3, 2020

Copyright $\odot 2020$ by author(s) and Scientific Research Publishing Inc. This work is licensed under the Creative Commons Attribution International License (CC BY 4.0).

http://creativecommons.org/licenses/by/4.0/

\section{(c) (i) Open Access}

\begin{abstract}
Although there is some consensus when it comes to establishing the lexicon as one of the strengths of language in people with Williams Syndrome (WS), little is known about its evolution throughout development and changes based on age. The objective of this study was to find out if there are differences in receptive vocabulary between childhood and adolescence and into adulthood. In this research, 19 people with WS between 6 and 20 years old, divided into two age ranges $(6-11 ; 12-20)$ and matched in mental age, were evaluated through the Peabody Vocabulary Test. The results show significant differences between both groups in favor of the group with the oldest chronological age and a direct correlation between chronological age and receptive vocabulary development, regardless of mental age. These data support the natural evolution of the passive lexicon in people with WS.
\end{abstract}

\section{Keywords}

Vocabulary Development, Williams Syndrome, Language, Development

\section{Introduction}

Williams Syndrome, hereinafter WS (Williams, Barratt-Boyes, \& Lowe, 1961; Beuren, Apitz, \& Harmjanz, 1962), is a neurodevelopmental disorder caused by a chromosome deletion on chromosome 7. Some studies claim that Williams syndrome has an incidence of 1 case per 7500 approximately (Rossi \& Giacheti, 2017; Strømme, Bjornstad, \& Ramstad, 2002). Others, on the other hand, say that the incidence is 1 in 20,000 (Garayzábal \& Cuetos, 2008; Sotillo, 1999).

WS is a multisystemic alteration that is reflected in the atypical neuroanatomic, physical-clinical, and neuropsychological phenotype. It manifests itself through cardiac and pulmonary alterations, prototypical facial features, and personality (Metcalfe, 1999; Rossi \& Giacheti, 2017). 
At the cognitive level, SW is characterized by a variable intellectual disability (with an IQ between 40 and 70), motor difficulties and alterations in visuospatial processing, planning, problem-solving and calculation (Arnold, Yule, \& Martin, 1985; Bellugi, Bihrle, Neville, Doherty, \& Jernigan, 1992; Puente, Fernández, Alvarado, \& Jiménez, 2014). In addition, in subjects with WS you can see a good memory of stimuli in the face of difficulties in other memory skills (Kaplan, Wang, \& Francke, 2001) and a dissociation between face processing, language and social cognition (Bellugi, Bihrle, Jernigan, Trauner, \& Doherty, 1990; Udwin, Yule, \& Martin, 1987). Chronological age did not relate significantly to cognitive abilities (Miezah, Porter, Batchelor, Boulton, \& Veloso, 2020).

Several studies have tried to describe a linguistic profile more open to individual variability (López-Rangel, Maurice, McGillivray, \& Friedman, 1992), although most seem to agree on the difficulty of grammatical aspects, lexical-semantic and pragmatic respectively (Clahsen \& Almazan, 1998; Levy \& Bechar, 2003; Pinheiro, Galdo-Álvarez, Sampaio, Niznikiewicz, \& Gonçalves, 2010; Robinson \& Temple, 2009). For example, at the morphosyntactic level, children with WS have difficulties in the use of prepositions, concordances of time, gender and number, a regulated structure and an average emission length lower than expected due to their chronological age (Benítez-Burraco, Garayzábal, \& Cuetos, 2016; Diez-Itza, Martínez, Fernández-Urquiza, \& Antón, 2017; Garayzábal, Sotillo, \& Campos, 2001; Grant, Valian, \& Karmiloff-Smith, 2002). The pragmatic component also seems to have certain particularities, especially as regards communicative exchanges. People with WS seem to have difficulties in the beginning and the end of the conversation. Besides, they do not take into account the information provided by the interlocutor or difficulties in the respect of shifts presenting, also, very imaginative messages, close to lyricism and empty content (Bellugi, Wang, \& Jenigan, 1994; Garayzábal, Fernández, \& Díez-Itza, 2010; Sotillo \& Garayzábal, 1999).

Specifically regarding the lexical component, it seems that people with SW have a broad and fluid vocabulary (Wang \& Bellugi, 1993). Heinze \& Vega (2010) maintain that subjects with WS obtain scores higher than people with same mental age in the tests that evaluate the passive lexicon in accordance with Brock (2007). In this same line, Arnold et al. (1985) \& Udwin et al. (1987) show that, on the Wechsler intelligence scales, people with SW score higher on vocabulary tasks (Davies, Howlin, \& Udwin, 1998), this being the component with the least difficulties. When using tasks that measure receptive vocabulary, again the data indicate that their scores are generally above their mental age, although below their chronological age (Bellugi et al., 1990; Tyler et al., 1997), which could indicate difficulties in lexical recovery. In addition, people with SW get a higher level of understanding vocabulary compared to other intellectual disabilities, such as Down syndrome (Ypsilanti, Grouios Alevriadou, \& Tsapkini, 2005). Other authors indicate that the performance in vocabulary tasks in the WS's case is relatively good except in relational vocabulary (Heinze, Osorio, Lens, \& Sampaio, 2014; Mervis \& John, 2008). 
In addition, at younger ages there are no differences in lexical task performance between DS and WS. However, in older ages, people with SW lower level of receptive vocabulary and lexical-semantic knowledge (Purser, Thomas, Snoxall, Mareschal, \& Karmiloff-Smith, 2015).

Longitudinal studies with children and adolescents with WS state that vocabulary skills decrease as age increases (Mervis \& Pitt, 2015).

It should also be noted that lexical acquisition skills and semantic knowledge are altered in the WS, with a different semantic processing system (Thomas, Dockrell, Messer, Parmigiani, Ansari, \& Karmiloff-Smith, 2006) and poorer compared to children with Typical Development (Jarrold, Hartley, Philips, \& Baddeley, 2000). However, the semantic component of individuals with WS seems to have a different development, far from being delayed (Gosch, Stading, \& Pankau, 1994; Von Armin \& Engel, 1964). Therefore, the aim of the study was to know the evolution of receptive vocabulary in children and adolescents with WS throughout age.

\section{Method}

\subsection{Participants}

This research involved 19 people diagnosed with WS (12 men and 7 women) divided into two age groups: 6 - 12 years (11 children) and 8 adolescents and adults between 12 and 20 years. The first group had a chronological mean age of 8.97 years (2.1), while the second group had a chronological mean age of 16.62 years (3.35). Taking into account that WS is considered a rare disease, and according to the data of the Williams Spain Association, the sample of this study represents $20 \%$ of its members.

Since intellectual capacity could explain the differences, the intelligence of all participants has been assessed beforehand. Both groups were paired in Intellectual Quotient (IQ) across the Weschler scales, specifically the WISC IV scale (Wechsler, 2010), with no significant differences between the groups. The children's group had an average IQ of 48.7 (2.7), while the adolescent group had an average IQ of 46.9 (2.1).

It is important to note that none of the participants attend speech therapy. In addition, all participants have Spanish as their mother tongue.

\subsection{Procedure}

In order to collect data, first of all, the Williams Spain Association was contacted and they proceeded to explain what the study was going to consist of, providing all the information related to the project and resolving any possible doubts that might arise. Once the association agreed to confirm the subjects that make up the first group of the sample, they proceeded to send an informed consent model so that parents who were interested in participating could sign them. At the same time, various educational centers were contacted in the same way to obtain the sample that makes up the group corresponding to the participants with typi- 
cal development (TD).

After this process, the administration of the evaluation test would be carried out. In the case of the group with WS, data collection was carried out at the anual meeting, organized by the association once a year. The data of the group with DT for their part, were acquired after carrying out the assessment process at the home of each one of them. It is important to bear in mind that all participants were evaluated individually and in a single session.

\subsection{Instrument}

The Peabody Picture vocabulary test (PPVT-III Spanish version of Dunn, Dunn and Arribas, 2006), designed to be used from the age of 2 years, was used to obtain data. The main objective of this test is to evaluate the level of receptive vocabulary.

\subsection{Data Analysis}

The normality of the sample was verified through the Kolmogorov-Smirnoff test, resulting in a non-parametric test. The results were then analyzed using the U-Mann Whitney test. To analyze the correlation between chronological age and linguistic age, Spearman's Rho test was used.

\section{Results}

The results show a higher level of receptive vocabulary in the group of adolescents and adults. As for the average linguistic age of the first group (6 - 12 years), it was 5.58 years (1.66), with a gap of 3.39 years over the chronological age. Meanwhile, in the second group of adolescents and adults, the mean age of language was 7.88 years (1.36), with a gap of 8.74 years over the chronological age. The results, therefore, indicate that there are significant differences between the two age groups $(p<.01)$.

Similarly, it has been found that there is a significant correlation $(<.01)$ between chronological age and language age.

\section{Discussion}

The data obtained in this research have shown how people with SW obtain results in designation tasks far below what would correspond to their chronological age, in the same line as studies carried out in naming tasks and word initiation (Bello, Capirci, \& Volterra, 2004). In addition, in this case, and regardless of the intellectual level, it is observed how the passive lexicon is improving as the chronological age increases, as pointed out by other studies that have used the same evaluation test, both comparing the mental age (Bellugi et al., 1990), as chronological age (Mervis, Morris, Bertrand, \& Robinson, 1999).

Along these lines, some authors suggested that the semantic system in SW could improve with age (Clahsen, Ring, \& Temple, 2004; Temple, Almazan, \& Sherwood, 2002) or that semantic knowledge is one of the strengths in adults 
(Brock, Jarrold, Farran, Laws, \& Riby, 2007). The results confirm that there is indeed an evolution in receptive vocabulary between childhood and adolescence and adulthood.

This could be interpreted according to studies that state that the pattern of vocabulary development is the same as that of typically developing children, despite language delay and SW delay. Originally, there is a gradual appearance of words that is later accompanied by a significant period of vocabulary learning (Robinson \& Mervis, 1998; Temple et al., 2002). However, other studies support that vocabulary acquisition in SW follows a different pattern compared to other intellectual disabilities, such as the case of Down syndrome (Vicari, Caselli, Gagliardi, Tonucci, \& Volterra, 2002). Compared to people with typical development, in WS, the vocabulary develops more slowly and with a higher level of production than understanding (Nazzi \& Karmiloff-Smith, 2002; Tyler et al., 1997).

It is important to note that these results are also in line with those studies that maintain that there is an asynchrony between cognitive development and lexical development characteristic of this syndrome (Nazzi, Gopnik, \& Karmiloff-Smith, 2005) but with interdependence between language and cognition (Mervis \& Becerra, 2007).

However, it should be noted that this significant difference in receptive vocabulary has occurred in a "natural" manner, as participants had not received speech therapy after the age of 6 , which indicates that the passive lexicon evolves as a distinctive feature in SW (Purser et al., 2015). It is also essential to highlight the importance of evaluating language skills in the context of adaptive functioning to guide the educational and rehabilitation strategies of people with SW (Alfieri et al., 2017). These results indicate the importance of continuing to work on the receptive vocabulary at the linguistic level throughout the development of the person with WS. Therefore, linguistic intervention should be a fundamental area within their treatments.

In addition, we believe it is important to emphasize that it would be necessary to know in future lines of research how the linguistic intervention influences this group and analyze the effectiveness of this treatment, considering adaptive functioning.

\section{Conflicts of Interest}

The authors declare no conflicts of interest regarding the publication of this paper.

\section{References}

Alfieri, P., Menghini, D., Marotta, L., De Peppo, L., Ravà, L., Salvaguardia, F., Vicari, S. et al. (2017). A Comparison between Linguistic Skills and Socio-Communicative Abilities in Williams Syndrome. Journal of Intellectual Disability Research, 61, 866-876.

https://doi.org/10.1111/jir.12401

Arnold, R., Yule, W., \& Martin, N. (1985). The Psychological Characteristics of Infantile 
Hypercalcemia: A Preliminary Investigation. Developmental Medicine \& Child Neurology, 27, 49-59. https://doi.org/10.1111/j.1469-8749.1985.tb04524.x

Bello, A., Capirci, O., \& Volterra, V. (2004). Lexical Production in Children with Williams Syndrome: Spontaneous Use of Gesture in a Naming Task. Neuropsychologia, 42, 201-213. https://doi.org/10.1016/S0028-3932(03)00172-6

Bellugi, U., Bihrle, A., Jernigan, T., Trauner, D., \& Doherty, S. (1990). Neuropsychological, Neurological, and Neuroanatomical Profile of Williams Syndrome. American Journal of Medical Genetics, 37, 115-125. https://doi.org/10.1002/ajmg.1320370621

Bellugi, U., Bihrle, A., Neville, H., Doherty, S., \& Jernigan, T. (1992). Language, Cognition, and Brain Organization in a Neurodevelopmental Disorder. In Developmental Behavioral Neuroscience: The Minnesota Symposia on Child Psychology (Vol. 24, pp. 201-232). Hillsdale, NJ: Erlbaum.

Bellugi, U., Wang, P. P., \& Jernigan, T. L. (1994). Williams Syndrome: An Unusual Neuropsychological Profile. In Atypical Cognitive Deficits in Developmental Disorders: Implications for Brain Function (pp. 23-56). Hillsdale, NJ: Erlbaum.

Benítez-Burraco, A., Garayzábal, E., \& Cuetos, F. (2016). Syntax in Spanish-Speaking Children with Williams Syndrome. Journal of Communication Disorders, 60, 51-61. https://doi.org/10.1016/j.jcomdis.2016.03.001

Beuren, A. J., Apitz, J., \& Harmjanz, D. (1962). Supravalvular Aortic Stenosis in Association with Mental Retardation and a Certain Facial Appearance. Circulation, 26, 1235-1240. https://doi.org/10.1161/01.CIR.26.6.1235

Brock, J. (2007). Language Abilities in Williams Syndrome: A Critical Review. Development and Psychopathology, 19, 97-127. https://doi.org/10.1017/S095457940707006X

Brock, J., Jarrold, C., Farran, E. K., Laws, G., \& Riby, D. M. (2007). Do Children with Williams Syndrome Really Have Good Vocabulary Knowledge? Methods for Comparing Cognitive and Linguistic Abilities in Developmental Disorders. Clinical Linguistics \& Phonetics, 21, 673-688. https://doi.org/10.1080/02699200701541433

Clahsen, H., \& Almazan, M. (1998). Syntax and Morphology in Williams Syndrome. Cognition, 68, 167-198. https://doi.org/10.1016/S0010-0277(98)00049-3

Clahsen, H., Ring, M., \& Temple, C. (2004). Lexical and Morphological Skills in English-Speaking Children with Williams Syndrome. Williams Syndrome across Languages, 36, 221-244. https://doi.org/10.1075/lald.36.14cla

Davies, M., Howlin, P., \& Udwin, O. (1998). Adults with Williams Syndrome: Preliminary Study of Social, Emotional and Behavioural Difficulties. The British Journal of Psychiatry, 172, 273-276. https://doi.org/10.1192/bjp.172.3.273

Diez-Itza, E., Martínez, V., Fernández-Urquiza, M., \& Antón, A. (2017). Morphological Profile of Williams Syndrome: Typical or Atypical? In Language Development and Disorders in Spanish-Speaking Children (pp. 311-327). Cham: Springer. https://doi.org/10.1007/978-3-319-53646-0_15

Dunn, L. M., Dunn, L. M., \& Arribas, D. (2006). PEABODY, Test de vocabulario en imágenes. Madrid: TEA ediciones.

Garayzábal, E., \& Cuetos, V. F. (2008). Aprendizaje de la lectura en los niños con síndrome de Williams. Psicothema, 20, 672-677.

Garayzábal, E., Fernández, M., \& Díez, E. (2010). Guía de intervención logopédica en síndrome de Williams. Madrid: Ed. Síntesis.

Garayzábal, E., Sotillo, M., \& Campos, R. (2001). Morphological and Syntactical Problems in Williams Syndrome. Actas del Xth European Conference on Developmental Psychology-ECDP, Uppsala, 22-25 de agosto. 
Gosch, A., Städing, G., \& Pankau, R. (1994). Linguistic Abilities in Children with Williams-Beuren Syndrome. American Journal of Medical Genetics, 52, 291-296. https://doi.org/10.1002/ajmg.1320520308

Grant, J., Valian, V., \& Karmiloff-Smith, A. (2002). A Study of Relative Clauses in Williams Syndrome. Journal of Child Language, 29, 403-416. https://doi.org/10.1017/S030500090200510X

Heinze, E. G., \& Vega, F. C. (2010). Procesamiento léxico-semántico en el síndrome de Williams. Psicothema, 22, 732-738.

Heinze, E. G., Osório, A., Lens, M., \& Sampaio, A. (2014). Concrete and Relational Vocabulary: Comparison between Williams and Smith-Magenis Syndromes. Research in Developmental Disabilities, 35, 3365-3371. https://doi.org/10.1016/j.ridd.2014.07.055

Jarrold, C., Hartley, S. J., Phillips, C., \& Baddeley, A. D. (2000). Word Fluency in Williams Syndrome: Evidence for Unusual Semantic Organisation? Cognitive Neuropsychiatry, 5, 293-319. https://doi.org/10.1080/13546800050199739

Kaplan, P., Wang, P. P., \& Francke, U. (2001). Williams (Williams Beuren) Syndrome: A distinct Neurobehavioral Disorder. Journal of Child Neurology, 16, 177-190.

https://doi.org/10.2310/7010.2001.18071

Levy, Y., \& Bechar, T. (2003). Cognitive, Lexical and Morpho-Syntactic Profiles of Israeli Children with Williams Syndrome. Cortex, 39, 255-271. https://doi.org/10.1016/S0010-9452(08)70108-4

López-Rangel, E., Maurice, M., McGillivray, B., \& Friedman, J. M. (1992). Williams Syndrome in Adults. American Journal of Medical Genetics, 44, 720-729.

https://doi.org/10.1002/ajmg.1320440605

Mervis, C. B., \& Becerra, A. M. (2007). Language and Communicative Development in Williams Syndrome. Mental Retardation and Developmental Disabilities Research Reviews, 13, 3-15. https://doi.org/10.1002/mrdd.20140

Mervis, C. B., \& John, A. E. (2008). Vocabulary Abilities of Children with Williams Syndrome: Strengths, Weaknesses, and Relation to Visuospatial Construction Ability. Journal of Speech, Language, and Hearing Research, 51, 967-982. https://doi.org/10.1044/1092-4388(2008/071)

Mervis, C. B., \& Pitts, C. H. (2015). Children with Williams Syndrome: Developmental Trajectories for Intellectual Abilities, Vocabulary Abilities, and Adaptive Behavior. American Journal of Medical Genetics, 169, 158-171. https://doi.org/10.1002/ajmg.c.31436

Mervis, C. B., Morris, C. A., Bertrand, J., \& Robinson, B. F. (1999). Williams Syndrome: Findings from an Integrated Program of Research. In Neurodevelopmental Disorders (pp. 65-110). Cambridge, MA: MIT Press.

Metcalfe, K. (1999). Williams Syndrome: An Update on Clinical and Molecular Aspects. Archives of Disease in Childhood, 81, 198-200. https://doi.org/10.1136/adc.81.3.198

Miezah, D., Porter, M., Batchelor, J., Boulton, K., \& Veloso, G. C. (2020). Cognitive Abilities in Williams Syndrome. Research in Developmental Disabilities, 104, Article ID: 103701. https://doi.org/10.1016/j.ridd.2020.103701

Nazzi, T., \& Karmiloff-Smith, A. (2002). Early Categorization Abilities in Young Children with Williams Syndrome. NeuroReport, 13, 1259-1262. https://doi.org/10.1097/00001756-200207190-00008

Nazzi, T., Gopnik, A., \& Karmiloff-Smith, A. (2005). Asynchrony in the Cognitive and Lexical Development of Young Children with Williams Syndrome. Journal of Child Language, 32, 427-438. https://doi.org/10.1017/S0305000904006737 
Pinheiro, A. P., Galdo-Álvarez, S., Sampaio, A., Niznikiewicz, M., \& Gonçalves, Ó. F. (2010). Electrophysiological Correlates of Semantic Processing in Williams Syndrome. Research in Developmental Disabilities, 31, 1412-1425. https://doi.org/10.1016/j.ridd.2010.06.017

Puente Ferreras, A., Fernández Lozano, M. P., Alvarado Izquierdo, J. M., \& Jiménez Rodríguez, V. (2014). Síndrome Williams: Una enfermedad rara con sintomatología contradictoria.

Purser, H. R., Thomas, M. S., Snoxall, S., Mareschal, D., \& Karmiloff-Smith, A. (2015). Definitions versus Categorization: Assessing the Development of Lexico-Semantic Knowledge in Williams Syndrome. International Journal of Language \& Communication Disorders, 1-13.

Robinson, B. F., \& Mervis, C. B. (1998). Disentangling Early Language Development: Modeling Lexical and Grammatical Acquisition Using and Extension of Case-Study Methodology. Developmental Psychology, 34, 363.

https://doi.org/10.1037/0012-1649.34.2.363

Robinson, S. J., \& Temple, C. M. (2009). The Representation of Semantic Knowledge in a Child with Williams Syndrome. Cognitive Neuropsychology, 26, 307-337. https://doi.org/10.1080/02643290903126320

Rossi, N. F., \& Giacheti, C. M. (2017). Association between Speech-Language, General Cognitive Functioning and Behaviour Problems in Individuals with Williams Syndrome. Journal of Intellectual Disability Research, 61, 707-718.

https://doi.org/10.1111/jir.12388

Sotillo, M. (1999). Aspectos psicológicos y cognitivos del síndrome de Williams. Escritos de Psicología, 3, 38-52.

Sotillo, M., \& Garayzábal, E. (1999). Socio-Communicative Abilities and Linguistic Abilities in Williams' Syndrome. Poster Presentado en IXth European Conference on Developmental Psychology, Spetses, 1-5.

Strømme, P., Bjomstad, P., \& Ramstad, K. (2002). Prevalence Estimation of Williams Syndrome. Journal of Child Neurology, 17, 269-271.

https://doi.org/10.1177/088307380201700406

Temple, C. M., Almazan, M., \& Sherwood, S. (2002). Lexical Skills in Williams Syndrome: A Cognitive Neuropsychological Analysis. Journal of Neurolinguistics, 15, 463-495. https://doi.org/10.1016/S0911-6044(01)00006-9

Thomas, M. S., Dockrell, J. E., Messer, D., Parmigiani, C., Ansari, D., \& Karmiloff-Smith, A. (2006). Speeded Naming, Frequency and the Development of the Lexicon in Williams Syndrome. Language and Cognitive Processes, 21, 721-759.

https://doi.org/10.1080/01690960500258528

Tyler, L. K., Karmiloff-Smith, A., Voice, J. K., Stevens, T., Grant, J., Udwin, O., Howlin, P. et al. (1997). Do Individuals with Williams Syndrome Have Bizarre Semantics? Evidence for Lexical Organization Using an On-Line Task. Cortex, 33, 515-527. https://doi.org/10.1016/S0010-9452(08)70233-8

Udwin, O., Yule, W., \& Martin, N. (1987). Cognitive Abilities and Behavioural Characteristics of Children with Idiopathic Infantile Hypercalcaemia. Journal of Child Psychology and Psychiatry, 28, 297-309. https://doi.org/10.1111/j.1469-7610.1987.tb00212.x

Vicari, S., Caselli, M. C., Gagliardi, C., Tonucci, F., \& Volterra, V. (2002). Language Acquisition in Special Populations: A Comparison between Down and Williams Syndromes. Neuropsychologia, 40, 2461-2470. https://doi.org/10.1016/S0028-3932(02)00083-0

Von Armin, G., \& Engel, P. (1964). Mental Retardation Related to Hypercalcaemia. De- 
velopmental Medicine \& Child Neurology, 6, 366-377.

https://doi.org/10.1111/j.1469-8749.1964.tb08138.x

Wang, P. P., \& Bellugi, U. (1993). Williams Syndrome, Down Syndrome, and Cognitive Neuroscience. American Journal of Diseases of Children, 147, 1246-1251. https://doi.org/10.1001/archpedi.1993.02160350120019

Wechsler, D. (2010). Wisc-IV: Test de inteligencia para niños (No. 159.9. 072). Paidós.

Williams, J. C. P., Barratt-Boyes, B. G., \& Lowe, J. B. (1961). Supravalvular Aortic Stenosis. Circulation, 24, 1311-1318. https://doi.org/10.1161/01.CIR.24.6.1311

Ypsilanti, A., Grouios, G., Alevriadou, A., \& Tsapkini, K. (2005). Expressive and Receptive Vocabulary in Children with Williams and Down Syndromes. Journal of Intellectual Disability Research, 49, 353-364. https://doi.org/10.1111/j.1365-2788.2005.00654.x 